\title{
HISTOPATHOLOGICAL STUDIES ON HUMAN LEPROSY
}

\author{
V. HISTOPATHOLOGICAL CHANGES IN THE LYMPHNODES \\ OF CHAULMOOGRA OIL ADMINISTERED HUMANS AND DOGS.
}

\author{
Kenji SUGAI \\ (Department of Pathology, National Leprosy Research Institute)
}

The histopathological changes in the lymphnodes of dogs injected intramuscularly with Chaulmoogra oil were investigated and the findings compared to those in man.

1) The intramuscularly injected Chaulmoogra oil was deposited in the regional lymphnodes and giant vacuoles and foreign body giant cells similar to those seen in the lymphnodes of the extremities in human leprosy were found.

2) A part of the Chaulmoogra oil administered by mouth is deposited in the mesenteric lymphnode system.

3) Lipoidemia occurs by both routes of administration and the lymphnodes throughout the body and the reticuloendothelial systems of the spleen and liver show a form of lipoidhistiocytosis. Granuloma formation however, was not observed.

4) There was an increase in fat loading of the erythrocytes and activation of the reticuloendothelial system with a marked increase in red cells and haemosiderin of the reticuloendothelial system.

\section{人 癩の 病理 組 織 学的研 究 第 5 報大風子油投与による人及び犬 リンパ腺の病理組織学的変化 菅并健 二 （1958 年 4 月 30 日受稿）}

\footnotetext{
緒 言

治瀨鼡としては, 昭和22年（療養所々長会議の際，プ ロミンの試用が提案された）頃までは，專ら大風子油が 用いられ，内服と筋肉注射とがエネルギッシュに施され た1)。個々例の投与総量を明確に挙げ得ないが, 殊に結 節瀬の場合には, 相量多量に上つていると判断されるの
}

である。現在私共が取扱つている剖検例は嘗て此の大風 子油の大量投与を受けているので, 制リンパ腺脂肪沈着 症の成因を考察する際, 此の事情を無視する事は出来な い。

今回, 此の様な見地から大風子油製剤安実験的に動物 に, 筋肉内及び経口的に投与してリンパ腺に於ける脂肪 沈着症の状況之組織化学的分析とを中心に検索してみた 
ので, 人癩リンパ腺の病像と比較し乍ら大風子油の影響 に就いて論ずる事としたい。

\section{実験材料及び方法}

実験には，肉食動物である事とリンパ腺の大きさを考

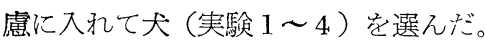

大 No. 1, 雑種: 5 cc の大風子油 (Oil Chaulmoogra, U. S. P., Amend Drug \& Chemical Co., New York) 1 回，左上膊筋に注射し， 3 日後に解剖した。

大 No. 2, 雑種: 大風子油 (武田薬化学研究所製) 学 $2 \mathrm{cc}$ 宛左上膊筋に, $1 \mathrm{cc}$ 宛を右上膊筋に夫々逼日注射し， 各々 9 回, 都合 $27 \mathrm{cc}$ 学投与した頃, 食㥕不振, 嘔昍, 全身衰弱等の症候を認めるに到つたので注射炎中止し， 3 日間様子を学観たが軽快しないので，チクロパソ $5 \mathrm{cc}$, 左大腿筋注射による深麻酔下に解剖した。

大 No. 3, 雑種: 大風子油 (武田薬化研) $35 \mathrm{cc}$ 学注射 筒を使つて無理に注入し，服用させた。投与期間は 3 日 で，3日目には既に食篎不振，脱力状態に陌り，4日目 には横臥するに到り，遂に死亡したので剖検を行つた。

大 No. 4, 雑種: 全量 $185 \mathrm{cc}$ の大風子油(武田薬化研) を 8 日間に亘つて投与した。本例も 4 日目より食㥕不振 となり，次第に衰弱安增したので，9日目は投与を中止 したが，翌10日目に死亡したので剖检を行つた。

経口投与の場合，1回量を5〜20cc としたが，巧く與 下せずに口外に洩し，又治えど每回嘔吐し，末期には 軽い下峲を伴つたりしているので，実際に吸収された量 ほ投与総量の ${ }^{1} / 2$ 〜 $/ 3$ 程度と思わ秃る。

組織標本は脂肪染色学中心とし，Baker の10\% ホル マリン・カルシウム固定, ゲラチン包埋・凍結切片に, オイルレッド 0-イソプロパノール（以下 ORO と略, Lillie, 1944), ナイル青加温染色 (Cain, 1947), Baker テスト (1946), Fischler 法 (1904), Schultz 法 (19245）等を施し，其の他パラフィン切片に対し一般染色を 行い, 必要に応じてメチル緑・ピロニンB染色 (Taft, 1951), $\mathrm{Fe}^{+++}$の為の Pearl 法 (Lison, 1936), 0.1\%千 オニン (Windle, 1943) 等を試みた。

\section{実 験 成 績}

実験 $\mathbf{1}$ ：大風子油注射を施した左側の深腋窩リンパ腺 は末梢域 $2 / 3$ が黄白色を呈し, 且腫脹している。組織学 的に此の部分は著しい空胞形成があり，空胞は一般に楕 円乃至円形で，概称 $70 \times 50 \mu$ 程度であるが，大なるもの は $314 \times 183 \mu$ ，小なるものは $20 \mu$ 前後である。空胞の 多くはリンパ洞に一致して存在するが，小空胞は滤胞又
は跹索内筷入を示す。一般に, 洞内皮は大円形細胞化し て, 開腔した洞を充たし, 他方浩胞及び䍸索の細網細胞 も肥大し, 一部では栄状繁殖像がみら机, 更に異物性巨 細胞吕出現している。全身のリンパ腺は軽度に腫脤し, メチル緑・ピロニン B 染色では, 著明な形質細胞の繁殖 像を認め, 同時に Russell 小体の出現も高度である。第 二次滤胞は肥大し, 中心の 細網細胞西増し (細網型), 肥大した網内系細胞は $1 \sim 7 \mu$ の暗黄色々素や变性赤血 球を含み，之等はプルシテン青反応陽性で，同系細胞の 食喰能の立進字示している。

実験 2 : 左右両側の浅・梁腋窩及び上鎖骨リンパ腺は 腫脹し, 割面では, 黄白色斑が一定の領域艺占めてい る。之は一定のリンパ管を経て大風子が般入されたと解 粏される。沈着程度は倍量注射した左側の方が高度であ るが，組総像からは左右に於ける本質的な差異はなかつ た。本例は, 大小の空胞が然数に存在し, 互に連結して 所謂サボテン状 (cactus style) 它示し，皮質では第二次

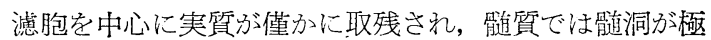

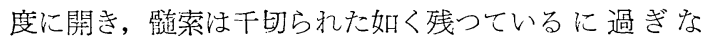
W。

組織化学的には, Baker, Fischler 法に陽性を示し, Schultz 法では赤紫色をとり，12 時間以上放置して後, 検鏡すると淡青緑色に変色していた。ナイル青では美し い赤橙色をとる。此の所見は人瀨リンパ腺の空胞内脂質 の性状に近い。

他部位のリンパ腺をみると，脂肪顆粒を貪喰した細網 細胞定少数認的る。洞内皮の肥大・繁殖方目立占，血鉄 素乃至变性赤血球の貪喰も盛である。文形質細胞の発生 も著明であり，肥胖細胞も多い。

興味のある所見として, 肺の脂肪染色慗本では, 肺胞 中隔の毛細血管が脂肪栓塞を起しており，又肋膜下乳斑 に多数の脂肪顆粒細胞が認められる。組織化学的には, 栓塞脂肪は Baker, Fischler 法に陽性, Schultz 法に陰 性 (褐色), ナイル青に赤染し, 乳斑の細胞内脂肪顆粒 は Baker, Fischler 及び Schultz (青緑色) 陽性, ナイ ル青に濃青染する。

肝は高度の脂肪肝安呈し, 脂肪化は細葉一中心带に强 く, $7 \mu$ 前後の小空胞が出現し, 此の部はナイル青に淡 赤染し, 細葉一周辺帯の淡紫染反応とほやや趣学異にし, Baker, Fischler 法も細葉一中心带に強く出る。 Schultz 法は陰性であつた。

Kupffer 星細胞は血鉄素を食喰しているが，脂肪含有 は極めて僅かであつた。

少肺に認められた脂肪栓塞の血行性由来を解釈する為 
に, 脾臟を検索してみると，脾梁静脈は管禁直し，その血 獎が ORO に染着され，赤血球も僅か乍ら染着されてお り, 細静脈では脂肪栓塞に近い像も見られ, 梁周囲性に ORO に染末る血獎の參出があり，更にリンパ滤胞一周 辺带に少数の脂肪顆粒細胞が認められ，所謂脾細胞も僅 か乍ら脂肪顆粒を貪喰している。即ち注射投与された大 風子油の大部分は流域リンパ腺に達し, 一部分が肺循環 岂経て後，大循環系に入り，肝臟に於て集約されると共 に全身の網内系に分散される事になる。

実験 3 ：肉腿的に, 閒脈に沿つた腸間膜リンパ腺は著 しく腫脹し，割面では灰白黄色を呈するものが多い。 $\mathrm{O}$ RO 染色標本では，腸間膜リンパ腺の或物は皮洞及び成道 洞に沿つて脂肪の強い沈着が認められるが，之は微細な 脂肪顆粒の重畳で，注射投与による流域リンパ腺内沈着

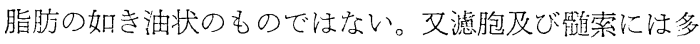
数の脂肪顆粒細胞が認められる。此の脂肪顆粒細胞は全 身のリンパ腺に一律に認豞られ，血行性由来のものであ る。

組織化学的には, 洞内脂肪はナイル青に淡紫染し, Baker, Fischler 及び Schultz 洁に何れも㓌性で，他方 脂肪顆粒細胞はナイル青に濃青染し, Baker 陽性, Fischler 陰性, Schultz 陽性（青緑色）を示した。

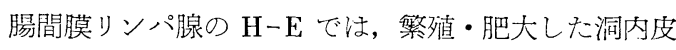
細胞が洞を充たし，变性赤血球やリンパ球を食喰してい る。滤胞及び髄索の細網細胞の肥大 $(15 \mu$ 前後) も著明 で，中には $15 \times 35 \mu$ に達するものもみられ，プルシアン 青反応陽性の色素顆粒や小球，その他小空胞等を含有し ている。第二次滤胞は細網型，或は硝子型を示し，核崩 壊もみら尗る。其の他実質に於ける形質細胞の発生も強 く, 網内系の賦活化が認为られる。此の様な網内系の被 刺娀状態は全身のリンパ腺に共通して認められる变化で ある。

本例も肺胞中隔毛細血管の脂肪栓塞, 静脈内血漿の 0 RO一染着性，肋膜下及び肺胞中隔乳斑に於ける典型的 な脂肪顆粒細胞の出現，肪脂肝の発生等がみら机た。劣 肝臓の Kupffer 星細胞汪多くの血鉄素を貪喰している が, 脂肪顆粒含有量は少い。

組織化学的には肺乳斑の脂肪顆粒が Baker, Fischler, Schultz (青緑色) に夫々陽性を示し, 肺の栓塞脂肪, 血 管内血漿は Baker, Fischler 法共に㓌性で, Schultz 法に 陽性（青緑色）を示した。之はコレステン而症意味す

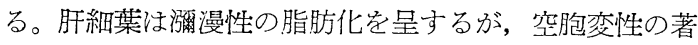
明な細葉一中心带がナイル青に淡紫〜淡赤染し, Baker, Fischler 及び Schultz 法は共に陰性であつた。脾蔵では
濾胞一周辺茾に多くの脂肪顆料細胞が見られ，脾細胞は 脂肪顆粒を多数頜喰して未り，脂肪顆粒は脾洞内にも認 められる。此の脂肪顆精はナイル青に青染, Baker 陽性, Fischler 㓌性, Schultz 陽性（青緑色）であつた。

実験 4 ：腸間膜リンパ腺の洞内脂枵沈着, 全身リンパ 腺に於ける網内系の被刺战状態，殊に脂肪顆粒絥胞の成

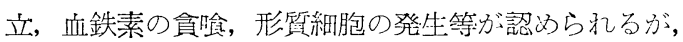
その程度は前例に此して遥かに高度で㐫る。

組織化学的には, 洞内脂肪はナイル青に淡紫染,

Baker, Fischler, Schultz 法注共に㓌性，脂肪顆粒細胞 はナイル青に濃青染, Baker 及び Fischler 法陰性, Schultz 陽性（青緑色）である。肋膜下及び肺胞中隔に 於ける乳斑の脂肪顆粒細胞, 細・中静脈内血墏の ORO 被染性及び Schultz 陽性 (青緑色) や脂肪肝は前例より も高度で, Kupffer 星細胞の脂肪含有量も多い。朋細葉 では Glisson 鞘に近接する一部を除いて $15 \mu$ 前後の空 胞 (ナイル青に淡紫〜淡赤染) 形成が一様に起つている。 之等の空胞は Baker, Fischler 及び Schultz 法に何れも 陰性であつた。脾茞に於けるリンパ湑胞内脂肪顆粒細胞 の発生，脾細胞の脂肪顆粒及び血鉄素貪喰及び脾洞内脂 肪顆粒の遊走も著明で，之等はナイル青に青染し， Schultz 陽性（青緑色），Baker 及び Fischler 法性㓌性で あつた。肺乳斑の脂肪顆粒細胞はナイル青に青染し， Schultz 陽性 (青緑色) を示すが，Baker 及び Fischler 法 は陰性で，前例の反応結果と異つている。

㤖本例には, 膵臓壞死が認められた。剖検時胆汁試験 は陽性であつたが，十二指腸カタルグ著明であつた。他 方肝の胆管上皮の脂肪顆粒分泌が強く, 胆露には胆汁が 充满していた。

\section{人瀨リンパ腺との比較考察}

先に私共が報告した人癩リンパ腺の变化と比較し乍ら 大風子油の影響を論じたい。人瀨四股リンパ腺と大風子 油注射犬の流域リンパ腺の組織像は凡同じであつて, 巨 大空胞形成，巨細胞の発生及び小空胞の介在等がみられ る。実験例では，巨大空胞は主として洞（滤胞の所謂中 間洞も含さ)采統にみられる。人瀨では, 被膜一線維症, 皮質, 空胞の集積及び腺門一線維症と言う樣に層が形成 される場合が多く，皮洞殊に辺縁洞には空胞汇通常みら 机ない。文檤質は正常の構築像としては認的難い。之は

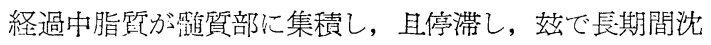
着するからであり，皮質は第二次滤胞を中心に再生する 為である。実験大に於ても第二次湑胞は周囲の滤胞が脂 質で充填された場合にも島状に取残されていて, 抵抗性 
の強さを示している。

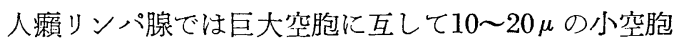
が多数存在する。之は注射した大の例にも見出される変 化であつて，之等は必ずしも癩病変のみに由来するもの ではない。

侗結節瀨の未治療例リンパ腺には既に霞漫性の泡沫組 織が認められる。此の場合に汇巨大空胞の集積はないし， 泡沫組織の ORO 染着度は一般に低い。時に辺緑洞及び 中間洞の一部が円形に開き，中に脂質 (ORO で淡橙色) 及び顆粒状菌客容れる事がある。之は末梢流域よりの脂 質及び菌のリンパ腺内搬入を意味し，一部ではリンパの 停滞による浮腫も亦リンパ腺の泡沫形成の作团になる。 リンパ腺脂肪沈着症はリン八腺の生物学的特性として, 様々な非抎散性物質が容易に流達し, 更に滤過される組 織であると言う基礎に立つて解翻されね枋ならぬと思 う。

人瀬リンバ腺では巨大空胞の存在と異物巨細胞の発生 とは深い関係がある。Leon Blanco \& Fite ${ }^{3)}$ は瀨球が变 性を起し, 異物化すると屡々異物性巨細胞が発生して之 を封鎖すると述べているが, リンハ腺の場合は原則とし て脂質に対する網内系の異物反忘として観察される。

人衤の内藏系, 殊に肝門, 膵リンパ腺等に脂肪沈着症 が起る事は既に知られている4a)が，確かに消化器系 (胃 十二指腸, 膵, 腸間膜及び腹腔) リンパ腺には所謂泡沫 組織が存在する（R-4.6 の場合，病歷によると大風子油 は 3 年間経口, 4 年間注射投与を受けている)。今回の 実験によると，経口投与の大風子油は晹間膜リンパ腺洞 系に微細顆粒の状態で高裴度に沈着し，一部は門脈を経 て脂肪肝觉も発生せしめ, 更に全身の絧内系に貪喰され る。

食斯性脂肪の吸収は腸に於て加水分解さ机ない場合は エマルジョン化してリンパ系に入り，一部は胸管を経て 血行に入り，加水分解された脂肪酸は陽粘膜で再び合成 されて脂肪となり，門脈多経て肝臟に入る ${ }^{5 \sim 6)}$ と言われ る。食聑性脂肪の場合と異り, 大風子油は消化器系リン パ腺にむしろ沈着されるのではないかと思われるが此の 問題に関しては更に長期間の観察が必要である。人瀨消 化器系リンパ腺脂肪沈着は沾胞や留道索に存在するが, 岸 粉症が洞系から次第に実質の細網細胞に固着される機転 を考光ると，実覧大の腸間膜リンパ腺洞系脂肪む異物と して実質の網内系に捕捉され，やがて沈着症を形成する に到るのではないかと思惟される。従つて人顸消化器系 リンパ腺脂肪沈着症も亦大風子油による作因を無視出来 ない。
大風子油投与によつて脂血症が起り，全身のリンパ腺， 肺乳斑及び脾の網内系に脂肪の貫喰が起る事は前述した が，此の網内系の系統的な Lipoidhistiocytosis は人倨》

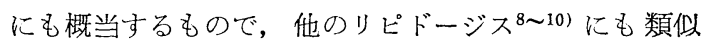
を求め得る。唯人瀬の場合, 肺乳斑, 岸粉症を伴う肺門 や気管支分岐部リンパ腺等には通常脂肪沈着症は認めら れず, 又逆に肝臟の Glisson 鞘, 中心静眽周囲或は Kupffer 星細胞, 副腎及び睪丸等に限局性巣状の脂肪沈着 が認められるのは実験例と趣を異にする。

勿論，攋に於ける如き病栄は単に脂血症の久では出現 しない。例咒ば脂血症を伴つた桾尿病肝の Kupffer 細星 胞には脂肪が含有され ${ }^{11)}$, 又田沼 ${ }^{12}$ は脂肪乳化液の静注 で，Kupffer 星細胞や Glisson 鞘に脂肪顆粒細胞が出現 する事を記载しているが, 今回の実験では Kupffer 星細 胞の脂肪掑取を認めても, Glisson 鞘に於ける脂肪顆粒 細胞は確認出来なかつた。又手許にある糖尿病肝（東大 -17570, 17617, 17788, 17853, 18089, 18272, 18304 及び印刷局東京病院-22）を調べたが瀨に於ける様な空 胞細胞の集積乃至栄形成の所見には接しなかつた。当然 顆の場合には, 瀬肉芽腫の組織発生に注意すべきであつ て, その構成体は組織球であり, 之が領喰能を有する事 は既に知られて衫り ${ }^{13 \sim 14)}$, 大風子油投与に上り脂血症が

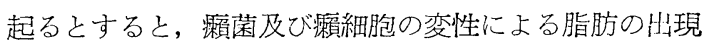
と注別途に，含脂性が修飾さ机る事は考えられる。

顆に於ては血鉄素がリンパ腺(b)や脾8)に大量に出現す る事が知られており, 他方脂肪乳化液の投与により脾に 血鉄素の沈着が起る事 ${ }^{12)}$ も確的ら机ているが，今回の実

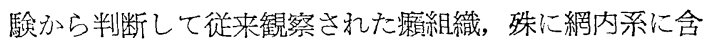
柰机る血鉄素は多分に大風子油の赤血球負荷に伴う赤血 球の変性汇起因していると考光られる。

脂肪肝は大風子油の投与量と共に増強するが，之を食 餌性一過性脂肪肝に類似学求导べきか, 将又肝臟毒作用 の結果と解释すべきかは脂肪肝の発生病理にも関連する ので更に椧討定加えたいと思う。

人瀬リンパ腺に於ける沈着脂肪（空胞内容物）は一般 に中性脂肪としての反心，Baker 及び Fischler 陽性の 傾向宗すが，之は注射投与の場合の成樍と似ている。 併し貪喰された細胞内脂肪顆粒に対する組織化学的結果 は区々であつた。此の点は原形質要素との関連に於て更 に追究されるね゙ならない。又経口投与の場合の腸間膜り ンパ腺洞内脂肪の消長を知る為にも, 上記空胞内脂質の 性状を人瀨のそれそ比較する場合，より適切である為に も長期観察が必要であると思われる。 


\section{結 論}

犬に大風子油を筋肉注射及び経口投与して，リンバ腺

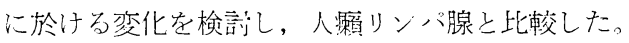

1）筋肉注射された大風子油は洗域リンー゚腺に沫，着

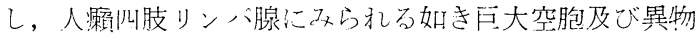
下細胞の!現を只た。

2) 経口投与された大風子油の一部は腸間膜リンー腺 洞に沈着するが，その消長に関しては更に長期の観察が 必要である。

3）何れの投与法によるも脂血症に陷り，全身のリン パ腺, 脾及び肝等:の網内采は一種の Lipoidhistiocytosis を呈する。併し肉芽腫形成は認められなかつた。

4）赤血球法肪負荷が増し，他方網内系の朐活化に より，変性赤血球貪喰及び血鉄索汢現が著明である。又 脂肪肝の発生も著明である。

(動物実験及び標本作製を援助して下さつた川津邦雄, 高橋泰衛及び中村東海の諸氏に心からの謝意を呈する）

\section{主要参考文献}

1) 光田健輔: 回春病室, P. $65-68$ 及び 231 , 朝日新聞 社（昭 25）

2 ）菅井健:-・福士勝成：人癞の病理組織学的研究（第 1 瓡）リン・头統の所見，レプラ 25，159-171(昭31)

3 ) Leon Blanco, F. \& Fite, G. L. : Silvering of lepra bacilli in tissues. Arch. Path., 46, 542-549 (1946)

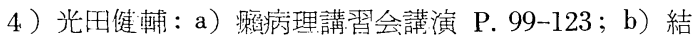

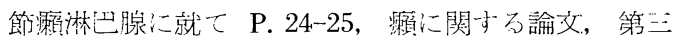
輯, 毞㵙会,（昭 25）

5 ) Frazer, A. C. \& Sammons, H. G.: The formation of mono- and diglycerides during the hydrolysis of triglyceride by pancreatic lipase. Biochem. J., 39, 122 $-128(1945)$
6) Rényi-Vámos, F.: Das Lymphgefässsystem des Dünndarms und seine Rolle in Fetttransport. Acta Medica Academiae Scientiarum Hungaricae, 9, 153-]64 (1956)

7 ) Tilden, I. L. : Lepromatous leprosy: A reticuloen dothelial disease. Histopathologic aspects. Am. J. Clin. Path.. 15, 165-177 (1945)

8 ) Lubarsch. O.: Pathologische Anatomie der Milz. Henke-Lubarschs Handbuch der speziellen pathologischen Anatomie und Histologie, I/2 S. 492-505 und 673-6ع3. Verlag von Julius Springer, Berlin (1927)

9 ) Gruber, G. B.: Die Leber bei Erkrankungen des blut- und lymphbildenden Gewebs-Apparates. Henke Lubarschs Handbuch der speziellen pathologischen Anatomie und Histologie, V/1, S. 666-686, Verlag von Julius Springer, Berlin (1930)

10) Auld, D. : Pathology of eosinophilic granuloma of the lung. Arch. Path., 63, 113-131 (1957)

11) Hanser-Ludwigshafen, R.: Atrophie, Nekrose, Ablagerungen und Speicherungen (sog. Degenerationen). Henke-Lubarschs Handbuch der speziellen pathologischen Anatomile und Histologie, V/1, S. 149-166. Verlag von Julius Springer, Berlin (1930)

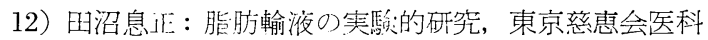
大学雑誌, 71，1841-1857 (昭 31)

13) Chuma, M. \& Gujo, K.: Eine histologische Untersuchung i.ber das Leprom mittels Vitalfärbung. Virchows Arch., 240, 469-.482 (1922)

14) Ryrie, G. A.: A preliminary report on the action of certain dyes in leprosy. International J. Leprosy, I. 469- 475 (1933) 


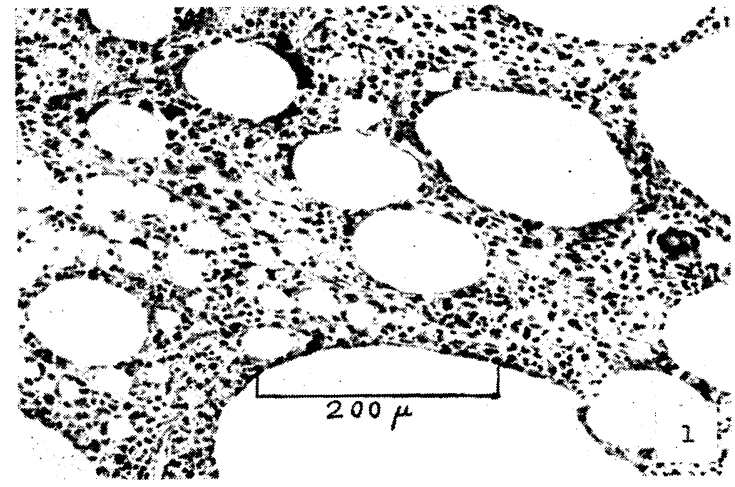

Fig. 1 大風子油注射，犬（実験-1)，左深脽 窩リン，腺，大小の空胞形成及び異物巨細 胞の出現。

$\mathrm{H}-\mathrm{E}, 200 \times$

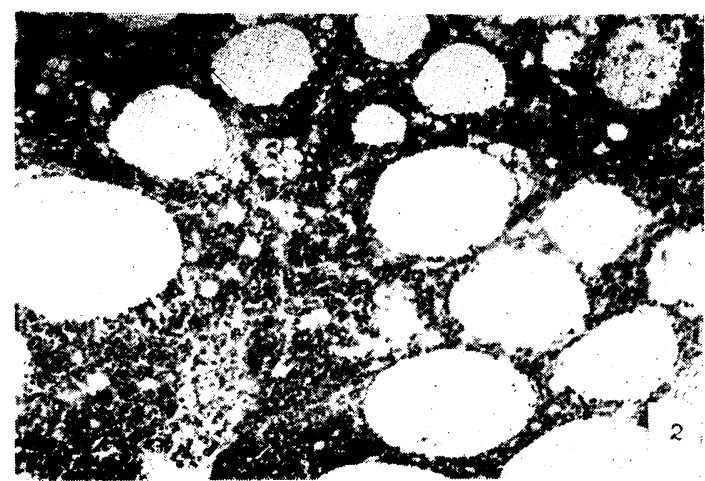

Fig. 2 結節嶰 $(\mathrm{R}-16)$, 左腋䆚リソパ腺, 大 小の空胞及び退行变性に陷つた異物性三細 胞（右上端及び尘胞の周辺）。

$\mathrm{H}-\mathrm{E}, 200 \times$

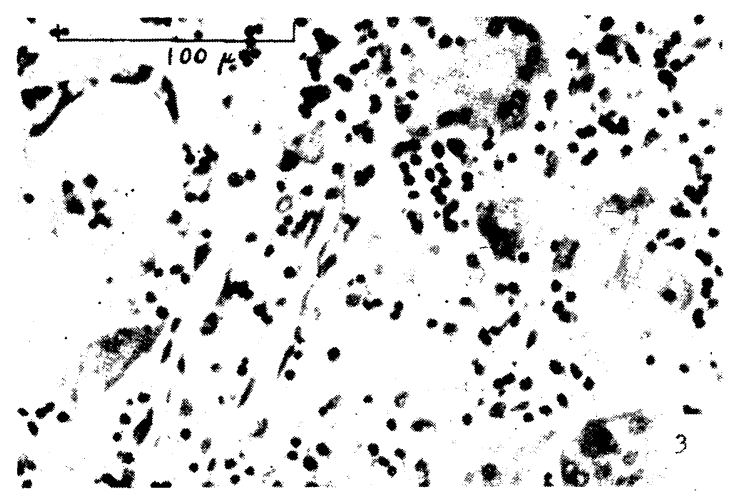

Fig. 3 結節瀨 $(R-1)$, 右脽窝リソパ腺, 貪 哙能の強い異物性巨細胞及び多数の空胞細 胞。

$\mathrm{H}-\mathrm{E}, 390 \times$

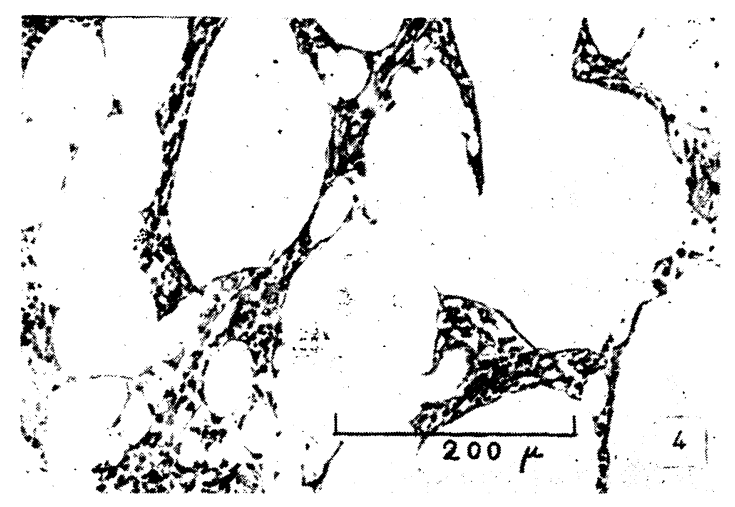

Fig. 4 大風油注射, 犬 (実験-2), 左腋窩り ソパ腺, 白大空胞, サボテン状空胞形成, 之は洞に於ける脂質の充填に依つて起つた 変化である。人瀨の場合 (Fig 6) と比較す ると與味が湧く。

$\mathrm{H}-\mathrm{E}, 200 \times$ 


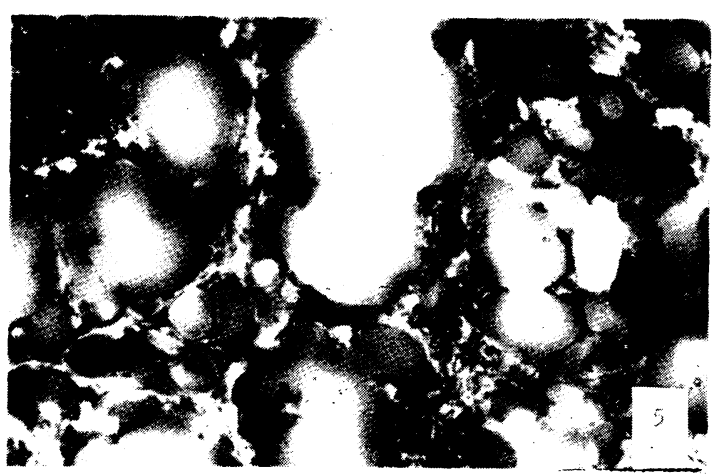

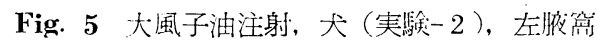
リン一湶, 脂肪（大風子油）り充填

O R O, $200 \times$

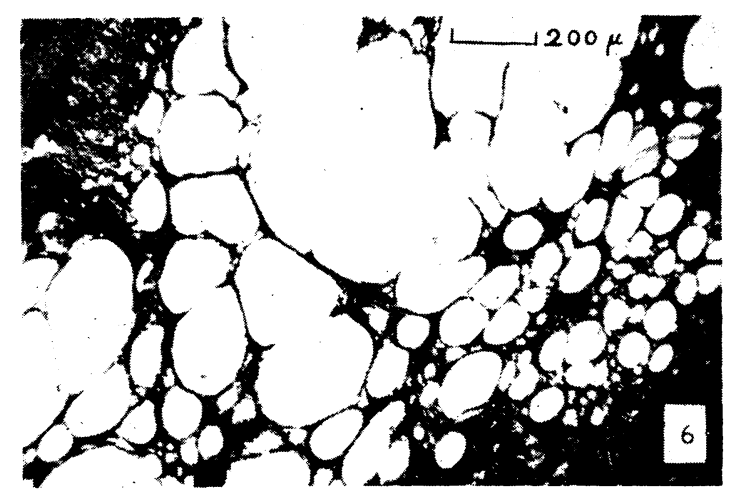

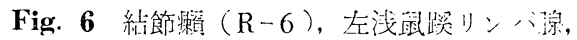
大小の空胞, サボテン状空胞, 被膜 (庄。: 部) 及びリンハ腺門（右下部）の強い線維

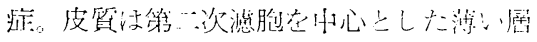

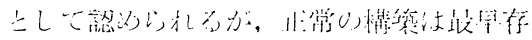
在しな。

Masson トリタローム, 53 メ

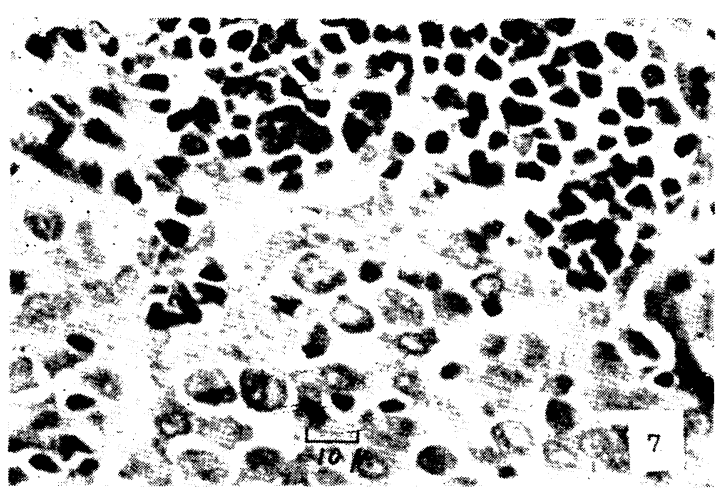

Fig. 7 大風子油注射, 犬（㿤験-1), 左樑腋

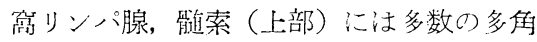
状のブラズマ細胞が発生し，洞（下部）の 内皮細胞は繁殖，肥大して遊離与方。此の 大円形細胞は暗黄色小球乃至顆粒（ブルシ アン青反心陽性）を貧唉している。 R E S 0䟼活が認的られる。

$$
\text { メチル緑・ビロニン B } 830 \times
$$

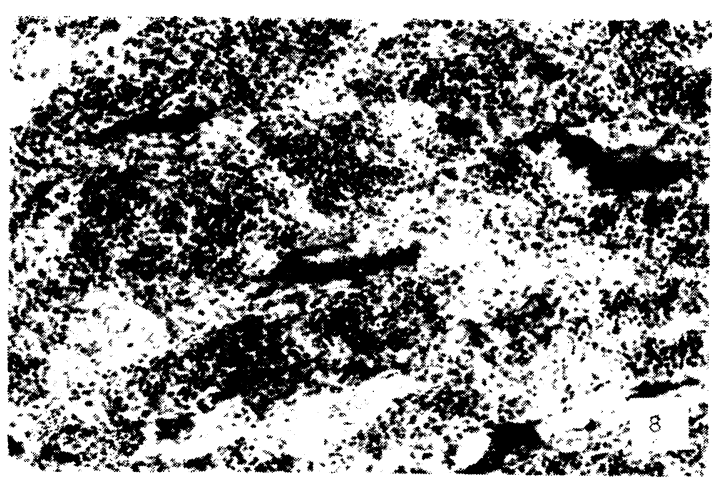

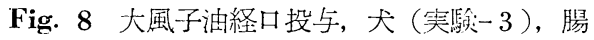
間膜リン・腺, 洞に注脂肪顆精の法氺が沈 着している。腸に於て消化, 吸収された大 風子油の一部がリン・腺に沈着吉当過程が うかがわ秃る。

$$
\text { O R O, } 200 \times
$$




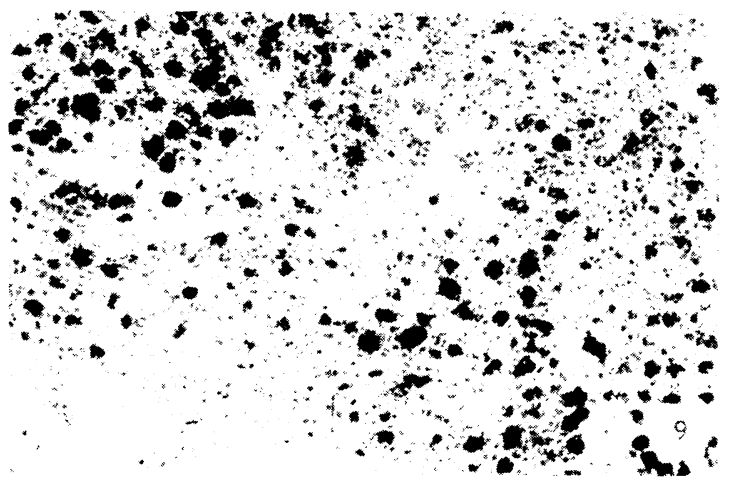

Fig.9大風子油注射, 大 (実験-4), 一下深頸

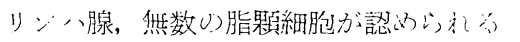
此の)種の变化は全身のリン八腺に一・律に一観 察される。

O R O, 200x

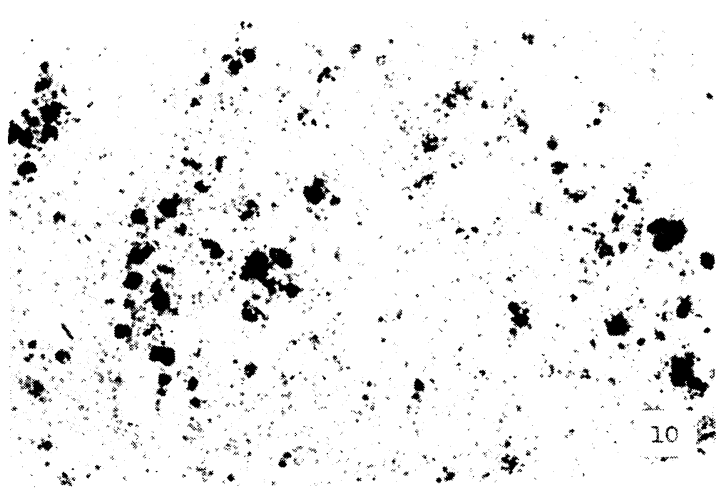

Fig. 10 結節濑 $(\mathrm{R}-45)$, 脾リン八腺に認的ら れ只脂顆細胞。

$$
\text { O R O, } 200 x
$$

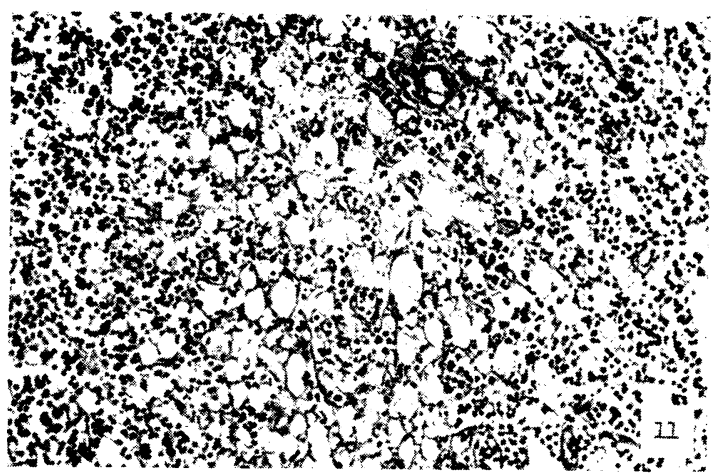

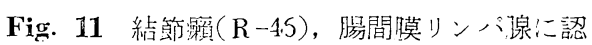
的ら机万多数の空胞形成。

$$
\mathrm{H}-\mathrm{E}, 200 \times
$$

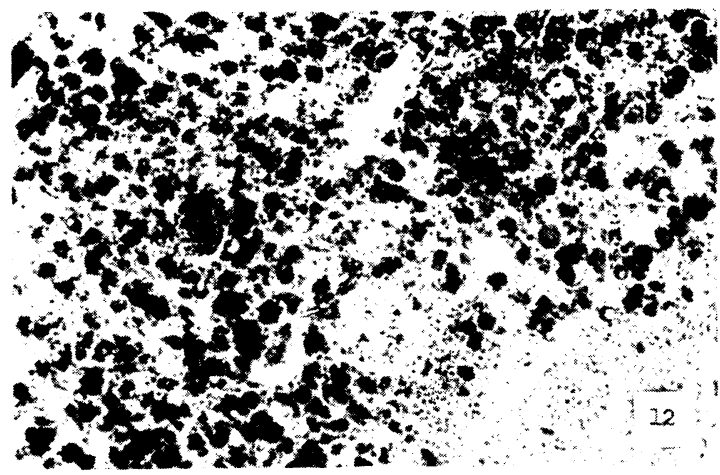

Fig. 12 結節獺 $(\mathrm{R}-46)$ ，舅小彎リンバ腺脂肪 沈着症，顆粒状万琹空胞状にして白大空胞 はない。

O R O , $200 \times$ 


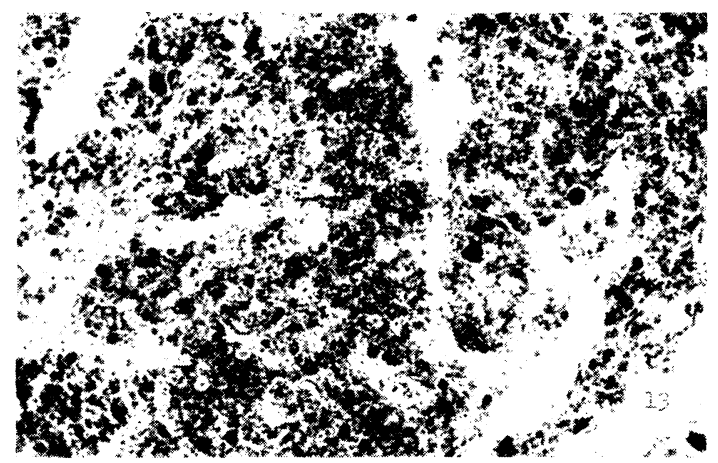

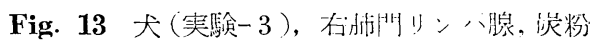

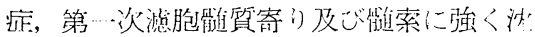

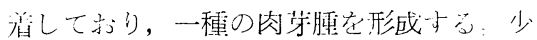
数さ脂顆細胞も見られる。

O R O, 200x

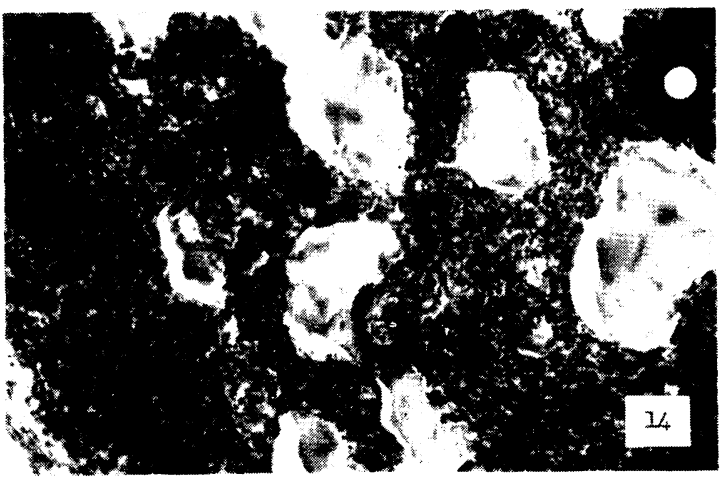

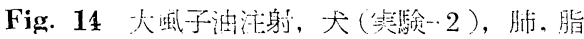

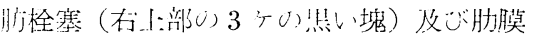
下乳斑○脂顆細胞（左緑，写真で㳉はつき り(な⿰力口。

O R O, $200 \times$

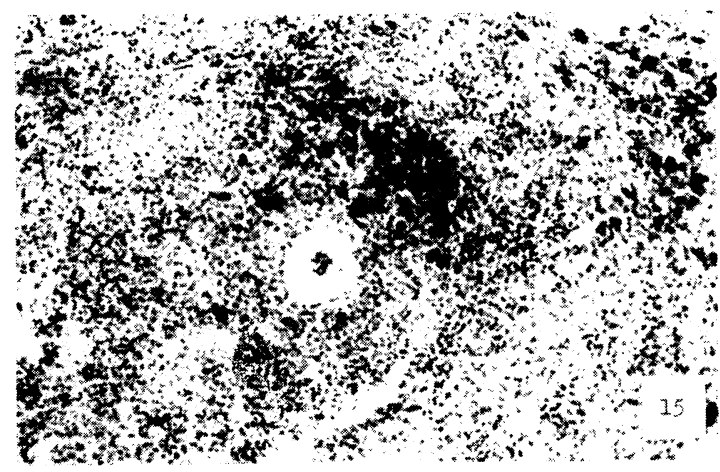

Fig. 15 大風子油注射，犬 $($ 実等余-4)，牌，リ ン八漼胞内の脂顆細胞, 脂肪顆粒が多数, 润にも存在与方。

O R O, $200 x$

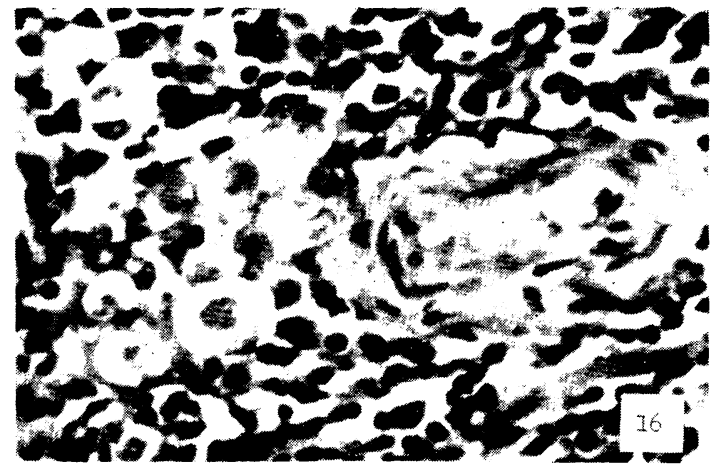

Fig. 16 大風于浊注射, 犬(锞駼一4), 脾, リ

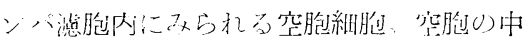
に活更にブルシナン青反心陽性小球万至顆

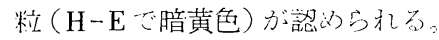

$\mathrm{H}-\mathrm{E}, 830 \times$ 


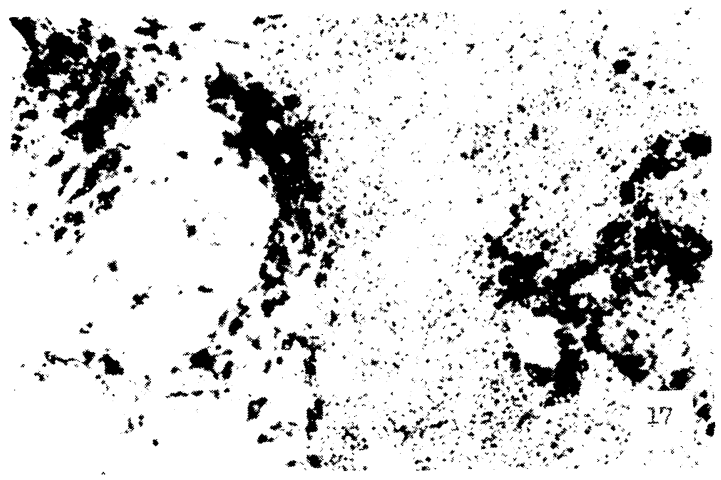

Fig. 17 絬節瀨 $(\mathrm{R}-46)$, 脾, 梁周团性, 中心

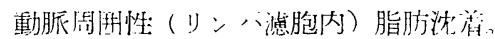
O R O, $200 \times$

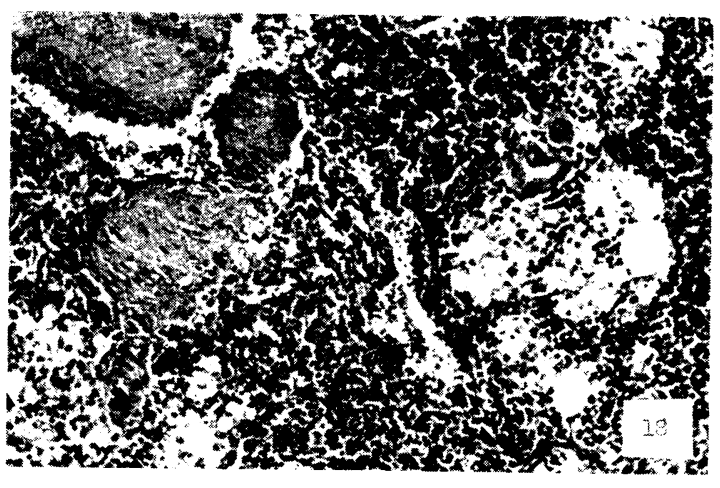

Fig. 18 絬節瀨 $(\mathrm{R}-46)$, 脾リンパ滤胞に於け

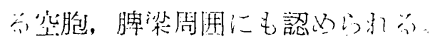

$$
\mathrm{H}-\mathrm{E}, 200 \times
$$

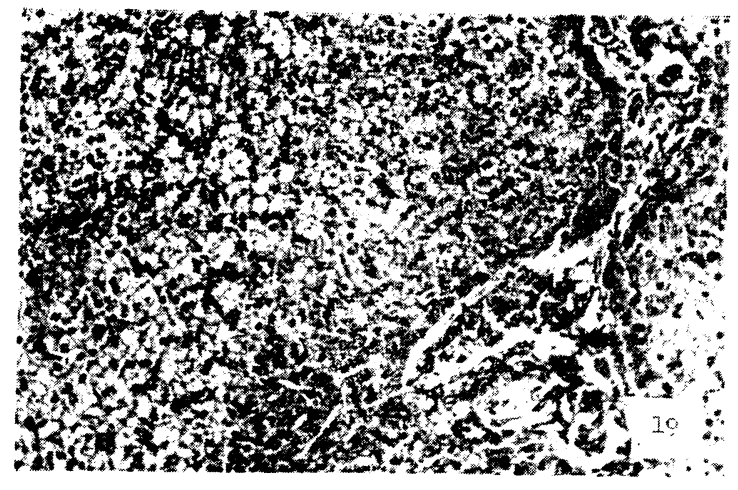

Fig. 19 大風子油経口投与, 犬(実䮖-4), 脂 肪肝。

$$
\mathrm{H}-\mathrm{E}, 200 \times
$$

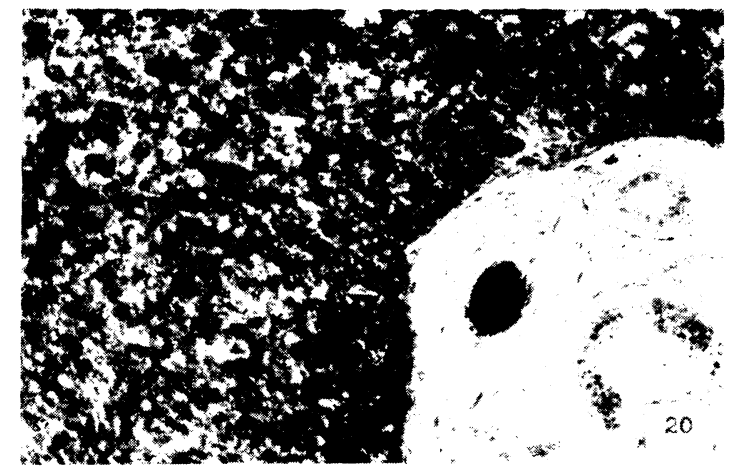

Fig. 20 大風子油経口投与, 犬(実騃-4), 脂 肪肝, 胆管（右下縁）上皮0)脂肪顆粒分泌 著明。

O R O, $200 \times$ 


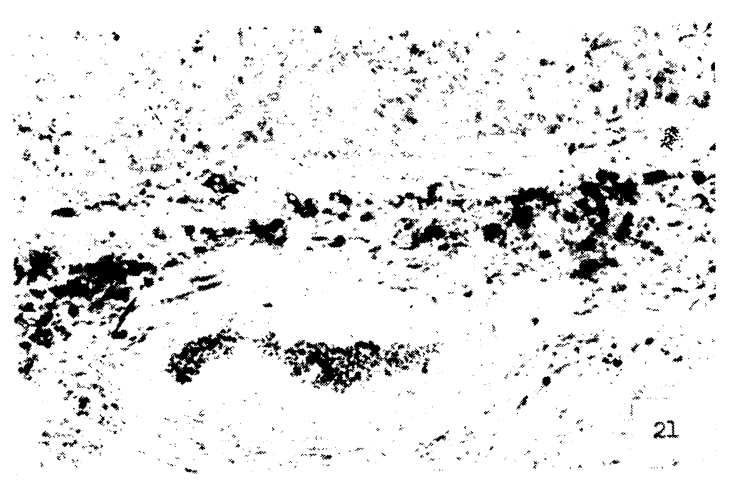

Fig. 21 結節瀨 $(\mathrm{R}-46)$, 肝 Glisson 鞘に認め られる脂肪小球及び顆粒。

O R O , $200 \times$

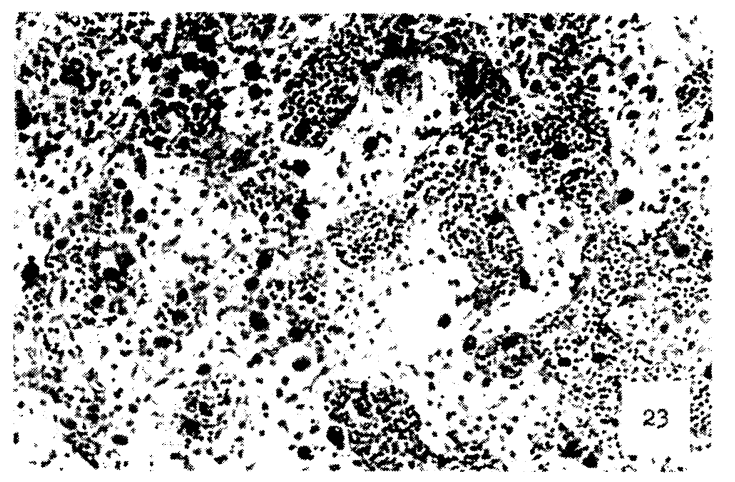

Fig. 23 大風子油経口投与, 犬(実駩 -3$)$, 腸 間膜リンー腺，プルシテン青反心陽性顆粒 及び小球が洞内皮細胞及び細網細胞に食哙 されている。

Pearl 法, $200 \times$

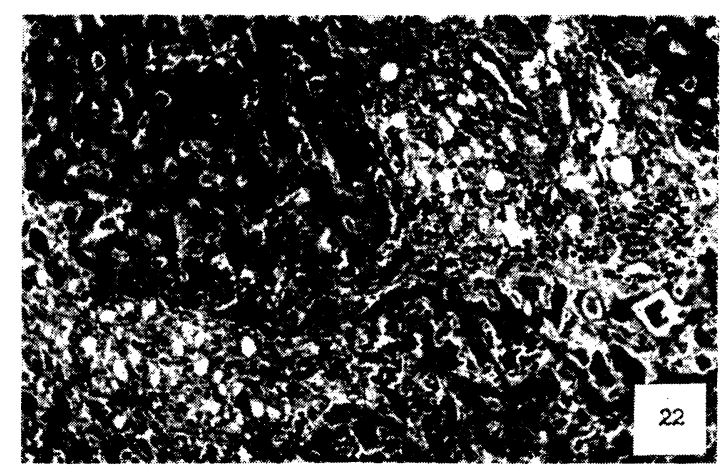

Fig. 22 結節瀨 $(\mathrm{R}-46)$, 肝 Glisson 鞘は軽い 線維症を伴い, 垫砲, 小円形細肘浸潤が認 わられる。

$$
\text { H-E, } 200 \times
$$

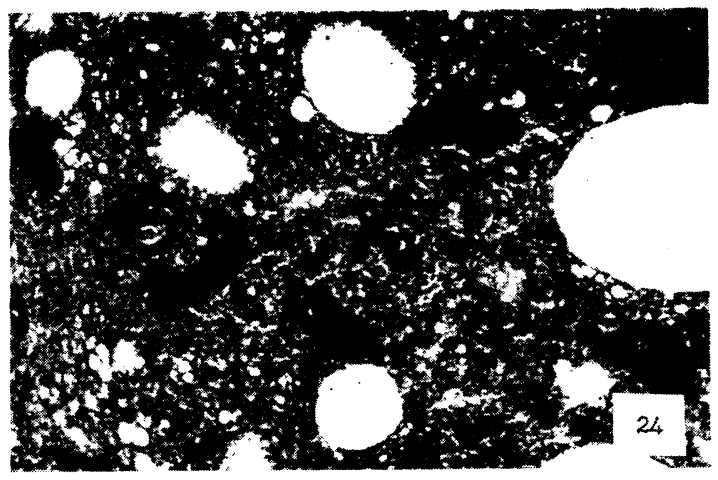

Fig. 24 絬節癩 $(\mathrm{R}-16)$, 右梁肘リンハ・腺, プ ルシナン青反㐫陽性顆粒及ざ小球が洞に充 洏していら。

Pearl 泣, $200 \times$ 